\title{
n-Butyrate Inhibition of Hyaluronate Synthesis in Cultured Human Fibroblasts
}

Terry J. Smith

Endocrine Section, Veterans Administration Medical Center, Augusta, Georgia 30910; Endocrine Section, Veterans Administration Medical Center, Buffalo, New York 14215; Department of Medicine, Medical College of Georgia, Augusta, Georgia 30912; and Department of Medicine, The State University of New York at Buffalo, Buffalo, New York 14215

\begin{abstract}
The effects of the short-chain aliphatic carboxylic acid, $n$-butyrate, on glycosaminoglycan (GAG) accumulation were studied in cultured human skin fibroblasts. Normal fibroblast cultures were grown to confluence, shifted to a medium without or with n-butyrate for $24 \mathrm{~h}$, labeled with either $\left[{ }^{3} \mathrm{H}\right]$ acetate or $\left[{ }^{3} \mathbf{H}\right]$ glucosamine and analyzed for $\left[{ }^{3} \mathbf{H}\right]$ GAG and $\left[{ }^{3} \mathbf{H}\right]$ hyaluronate accumulation. Accumulation was stimulated at low concentrations (0.1-1 mM) by up to 27\%. Higher concentrations of $n$-butyrate (>1 mM) inhibited [ $\left.^{3} \mathrm{H}\right] \mathrm{GAG}$ by up to $70-90 \%$. This effect was maximal at $10 \mathrm{mM}$ and half-maximal at $3 \mathrm{mM}$. Propionate had similar effects but was less potent. Parallel studies conducted in colonic fibroblasts revealed that $\boldsymbol{n}$-butyrate could markedly inhibit $\left[{ }^{3} \mathbf{H}\right]$ GAG accumulation in that cell type as well. These effects were rapid, occurring within $3 \mathrm{~h}$ of treatment, and were reversible. Chondroitin sulfate accumulation was unaffected by the compound. A pulse-chase study failed to demonstrate any effect on $\left[{ }^{3} \mathbf{H}\right]$ GAG degradation.
\end{abstract}

\section{Introduction}

Human skin fibroblasts are a useful in vitro model for studying the synthesis and metabolism of glycosaminoglycans (GAG), ${ }^{1}$ which are complex carbohydrates involved in cellular attachment (1). These cells elaborate large amounts of GAG, predominantly hyaluronate (HA), as well as chondroitin sulfate and dermatan sulfate (2). Until recently, very little was understood about the mechanism involved in HA synthesis. Philipson and Schwartz have localized the incorporation of $\left[{ }^{14} \mathrm{C}\right]$ glucuronic acid from its uridine diphosphate donor into $\mathrm{HA}$ at the plasma membrane of oligodendroglioma cells (3). The nature of the enzyme(s) involved in the sequential transfer of $n$-acetyl glucosamine and glucuronic acid residues to $\mathrm{HA}$ and subsequent chain elongation, however, remain to be elucidated. Mechanisms involved in the control of this process are also incompletely understood. Earlier studies demonstrated that virus-transformed fibroblasts elaborate significantly more HA than do normal cells (2), and that GAG synthesis is disordered in cells from patients with osteogenesis imperfecta (4) and Marfan's syndrome (5), yet the proximate mediators of these alterations are as yet unidentified.

This laboratory has reported that both thyroid and glucocorticoid hormones can regulate $\left[{ }^{3} \mathrm{H}\right] \mathrm{GAG}$ accumulation in hu-

Address reprint requests to Dr. Smith, Endocrine Section, Veterans Administration Medical Center, Buffalo, NY 14215.

Received for publication 26 September 1986.

1. Abbreviations used in this paper: GAG, glycosaminoglycan; HA, hyaluronate.

The Journal of Clinical Investigation, Inc.

Volume 79, May 1987, 1493-1497 man skin fibroblasts $(6,7)$. Both classes of hormone inhibit $\left[{ }^{3} \mathrm{H}\right] \mathrm{HA}$ synthesis in a time- and dose-dependent manner $(6,7)$. The accumulation of sulfated GAG such as chondroitin sulfate and dermatan sulfate were unaffected by hormone treatment, however, which suggests a high degree of specificity.

Short-chain, naturally occurring aliphatic carboxylic acids recently have been found capable of a variety of biological effects on cells in culture, including alteration of specific gene expression (8). The latter effect is thought possibly to be a consequence of hyperacetylation of chromatin proteins (9). These compounds are present in high concentrations in human stool and the physiologic implication of their presence is now being appreciated. The current communication describes the results of studies that examine the effects of $n$-butyrate, a 4-carbon fatty acid, on $\left[{ }^{3} \mathrm{H}\right] \mathrm{HA}$ accumulation in skin and colonic fibroblasts.

\section{Methods}

\section{Materials}

Human skin and colon fibroblasts were obtained from American Type Culture Collection, Rockville, MD. $\left[{ }^{3} \mathrm{H}\right]$ Acetic acid $(2.8 \mathrm{Ci} / \mathrm{mmol} \mathrm{sp}$ act), $\left[{ }^{3} \mathrm{H}\right]$ glucosamine $(19.7 \mathrm{Ci} / \mathrm{mmol})$, and $\left[{ }^{35} \mathrm{~S}\right]$ sulfuric acid (carrier free) were purchased from New England Nuclear, Boston, MA and $\left[{ }^{3} \mathrm{H}\right]$ leucine $(50 \mathrm{Ci} / \mathrm{mmol})$ from ICN Pharmaceuticals, Irvine, CA. $n$-Butyrate, propionate, chondroitin sulfate, and pronase were obtained from Sigma Chemical Co., St. Louis, MO. HA was extracted from human umbilical cord. Sephadex G-50 (fine) was from Pharmacia Fine Chemicals, Piscataway, NJ and Streptomyces hyaluronidase and chondroitinase ABC from Miles Laboratories, Inc., Elkhart, IN. All other chemicals used were of the highest purity commercially available.

\section{Procedures}

Cell culture. Normal human fibroblasts were propagated in Eagle's minimal essential medium supplemented with Earle's salts, glutamine, penicillin/streptomycin, amphotericin B, and fetal calf serum (10\%). Cells were plated at a density of 400,000 per 60 -mm diam plastic dishes covered with $4 \mathrm{ml}$ medium and grown to confluence at $37^{\circ} \mathrm{C}$ in a humidified, $5 \% \mathrm{CO}_{2}$ incubator ( $\sim 10 \mathrm{~d}$ usually).

Carboxylic acids were dissolved directly in the medium. Treatment periods were usually $24 \mathrm{~h}$ unless indicated otherwise. This was followed by a 24-h labeling period, at the beginning of which fresh medium supplemented with $\left[{ }^{3} \mathrm{H}\right]$ acetate $(5-20 \mu \mathrm{Ci} / \mathrm{ml}),\left[{ }^{3} \mathrm{H}\right]$ glucosamine $(1-2 \mu \mathrm{Ci} /$ $\mathrm{ml})$, or $\left.{ }^{35} \mathrm{~S}\right]$ sulfuric acid $(10-25 \mu \mathrm{Ci} / \mathrm{ml})$ was added. Labeling periods were shortened in the time course experiments and in the pulse-chase study as indicated in the figure legends. The chase incubation of the later study involved unlabeled medium containing $1 \mathrm{mM}$ sodium acetate. $\left[{ }^{3} \mathrm{H}\right]$ Leucine $(5 \mu \mathrm{Ci} / \mathrm{ml})$ was added to the medium of cultures in studies assessing effects on protein synthesis.

Quantitation of $\left[{ }^{3} \mathrm{H}\right] \mathrm{GAG}$ and $\left[{ }^{3} \mathrm{H}\right] \mathrm{HA}$ accumulation. Details concerning the method of $\left[{ }^{3} \mathrm{H}\right] \mathrm{GAG}$ analysis have been published elsewhere (10). Briefly, culture media were collected quantitatively, cell layers rinsed with phosphate-buffered saline and then solubilized in $\mathrm{NaOH}(0.1 \mathrm{~N})$. Cellular material was then scraped off the substratum and disrupted by sonication. After an aliquot was removed for protein determination by the method of Lowry et al. (11), the cell layers, wash, and media were 
combined and subjected to pronase $(1 \mathrm{mg} / \mathrm{ml})$ digestion in $100 \mathrm{mM}$ Tris buffer, $\mathrm{pH} 8.0$ at $50^{\circ} \mathrm{C}$ overnight. After cooling on ice, the samples were precipitated with trichloroacetic acid $(5 \% \mathrm{wt} / \mathrm{vol})$ and centrifuged. The acid soluble material was collected and dialyzed extensively against cold water. The resultant material was counted by liquid scintillation spectroscopy and defined as total $\left[{ }^{3} \mathrm{H}\right] \mathrm{GAG}$. In some experiments, the postdialysis samples were lyophilized to dryness and subjected to Streptomyces hyaluronidase or chondroitinase $\mathrm{ABC}$ digestion (10). The digested material was separated by Sephadex G-50 column chromatography. In early studies, uronic acid content was determined by the method of Dische (12). Postdialysis and postchromatographic recoveries were uniform, as described previously (10).

Data are expressed either as the mean \pm range from duplicate cultures or as the mean \pm SEM of results from triplicate cultures. Statistical significances were determined by Student's $t$ test.

\section{Results}

$n$-Butyrate $(10 \mathrm{mM})$ substantially inhibited $\left[{ }^{3} \mathrm{H}\right] \mathrm{GAG}$ accumulation in confluent human skin fibroblast cultures when added to the culture medium $24 \mathrm{~h}$ before labeling. As Fig. 1 demonstrates, $\left[{ }^{3} \mathrm{H}\right]$ acetate and $\left[{ }^{3} \mathrm{H}\right]$ glucosamine incorporation into GAG were inhibited by $88(P<0.001)$ and $72 \%(P<0.001)$, respectively. Consistent with previous studies, $\sim 80-90 \%$ of the $\left[{ }^{3} \mathrm{H}\right] \mathrm{GAG}$ was Streptomyces hyaluronidase digestible, irrespective of treatment group, which defines the material as $\left[{ }^{3} \mathrm{H}\right] \mathrm{HA}$. Since the incorporation of both tritiated precursors was inhibited, the effect was not the result of gross metabolic pool alterations. Because the colon is exposed to high concentrations of butyrate and other carboxylic acids (13), colon fibroblast cultures were also exposed to $n$-butyrate $(10 \mathrm{mM}) .\left[{ }^{3} \mathrm{H}\right]$ Glucosamine $(1 \mu \mathrm{Ci} /$ $\mathrm{ml}$ ) incorporation into $\left[{ }^{3} \mathrm{H}\right] \mathrm{GAG}$ was inhibited by $57 \%$ (control, $147 \pm 25 \mathrm{dpm} / \mu \mathrm{g}$ protein vs. treated, $60 \pm 4 \mathrm{dpm} / \mu \mathrm{g}$ protein (mean \pm SEM), $n=3, P<0.005$ ).

Fig. 2 depicts the relationship between the medium concentration of $n$-butyrate and propionate (a 3-carbon carboxylic acid) and the magnitude of effect on $\left[{ }^{3} \mathrm{H}\right] \mathrm{GAG}$ accumulation. At 1 $\mathrm{mM}$ butyrate, $\left[{ }^{3} \mathrm{H}\right]$ acetate incorporation was slightly, but significantly, stimulated. The stimulatory effect of low doses of butyrate was confirmed in another experiment when treated cultures accumulated $2,160 \pm 144 \mathrm{dpm} / \mu \mathrm{g}$ protein vs. controls, $1,695 \pm 46 \mathrm{dpm} / \mu \mathrm{g}$ protein, $n=3, P<0.05)$, a $27 \%$ stimulation. At higher concentrations of $n$-butyrate (2-10 mM), accumulation was inhibited in a dose-dependent manner. The contour of the concentration curve for propionate was similar but shifted to the right, consistent with the previously reported relative potency

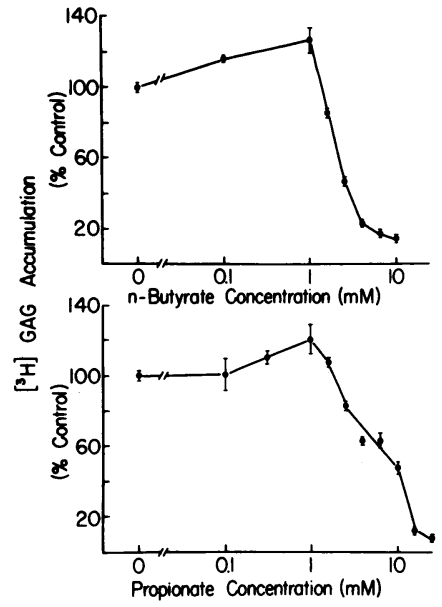

Figure 2. Effect of $n$-butyrate and propionate concentrations on $\left[{ }^{3} \mathrm{H}\right] \mathrm{GAG}$ accumulation. Confluent cultures were shifted for $24 \mathrm{~h}$ to medium supplemented with the various concentrations of carboxylic acid indicated along the abscissa. The cultures were then labeled for an additional day as described in the legend to Fig. 1 and then harvested. Each datum point indicates the mean \pm range of duplicate cultures.

of the two compounds (14). At respective concentrations of 10 and $40 \mathrm{mM}, n$-butyrate and propionate inhibited $\left[{ }^{3} \mathrm{H}\right] \mathrm{GAG}$ accumulation by $\sim 85 \%$.

Addition of $n$-butyrate ( $10 \mathrm{mM}$ ) to culture medium resulted in a rapid decline in $\left[{ }^{3} \mathrm{H}\right] \mathrm{GAG}$ accumulation. Within $3 \mathrm{~h}$ of treatment, the incorporation of $\left[{ }^{3} \mathrm{H}\right]$ acetate was $58 \%$ lower than in control dishes (Fig. 3). There was a further time-dependent decline until $9 \mathrm{~h}$, when $\left[{ }^{3} \mathrm{H}\right] \mathrm{GAG}$ accumulation in treated cultures was $22 \%$ of controls. When the medium from treated cultures was removed and replaced with untreated medium, incorporation increased rapidly, and first apparent within $\sim 6 \mathrm{~h}$ (Fig. 4). By $10 \mathrm{~h}$ of medium replacement, accumulation had approximated that found in untreated control cultures. Those cultures continually maintained in medium containing $n$-butyrate failed to demonstrate this recovery (Fig. 4).

To determine the specificity of the carboxylic acid inhibition of $\left.{ }^{3} \mathrm{H}\right] \mathrm{GAG}$ accumulation, confluent plates were treated for 24 $h$ at a concentration that yielded maximal results, labeled with $\mathrm{H}_{2}\left[{ }^{35} \mathrm{~S} \mathrm{O}_{4}(10 \mu \mathrm{Ci} / \mathrm{ml})\right.$, and $\left[{ }^{35} \mathrm{~S}\right] \mathrm{GAG}$ accumulation was quantitated. $n$-Butyrate failed to influence ${ }^{35} \mathrm{~S}$-incorporation into macromolecules (control, $1,089 \pm 84 \mathrm{dpm} / \mu \mathrm{g}$ protein vs. $n$-butyrate, $1,077 \pm 91 \mathrm{dpm} / \mu \mathrm{g}$ protein, mean \pm SEM, $n=3$, NS). Greater than $90 \%$ of the $\left[{ }^{35} \mathrm{~S}\right] \mathrm{GAG}$ was digestible by chondroitinase $\mathrm{ABC}$ digestion, defining it as chondroitin sulfate and dermatan sulfate. This is a key finding because it strongly suggests that $n$-butyrate is not simply competing with the labeled precursors at an important intermediate step. Similarly, total cellular

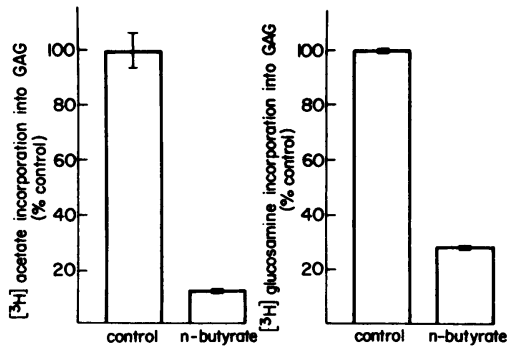
$\left[{ }^{3} \mathrm{H}\right]$ acetate $(5 \mu \mathrm{Ci} / \mathrm{ml})$ or $\left[{ }^{3} \mathrm{H}\right]$ glucosamine $(2 \mu \mathrm{Ci} / \mathrm{ml})$ for an additional day, and then harvested. Each column represents the mean of triplicate plates \pm SEM from one representative experiment. tyrate on the incorporation of $\left[{ }^{3} \mathrm{H}\right]$ acetate and $\left[{ }^{3} \mathrm{H}\right] \mathrm{glucosamine}$ into $\left[{ }^{3} \mathrm{H}\right]$ GAG. Confluent skin fibroblast cultures were incubated without or with $n$-butyrate $(10$ the same medium supplemented with either
Figure 1. Effect of $n$-bu$\mathrm{mM}$ ) for $24 \mathrm{~h}$, shifted to

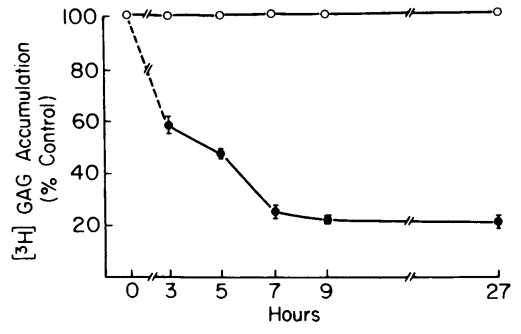

Figure 3. Time course of the effect of $n$-butyrate on $\left[{ }^{3} \mathrm{H}\right] \mathrm{GAG}$ accumulation. Confluent cultures were incubated without (open circle) or with (solid circle) $n$-butyrate $(10 \mathrm{mM})$ for the various durations of time indicated along the

abscissa. All cultures were labeled $2 \mathrm{~h}$ before harvest. Each symbol indicates the mean \pm range of duplicate cultures from one representative experiment. 


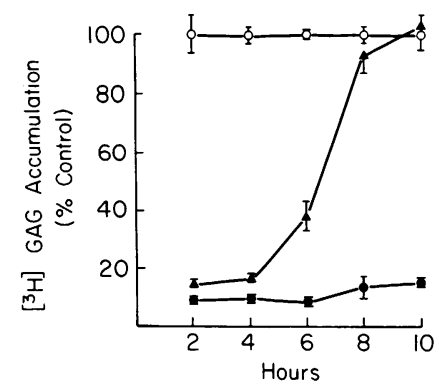

Figure 4. Time course of reversibility of the $n$-butyrate effects on $\left[{ }^{3} \mathrm{H}\right] \mathrm{GAG}$ accumulation. Confluent cultures were treated for $24 \mathrm{~h}$ with (solid triangle, solid circle) $n$-butyrate (10 mM) or (open circle) nothing, and then some carboxylic acid-treated cultures were washed and incubated with medium to which $n$-butyrate had

not been added (solid triangle). All cultures were labeled for $2 \mathrm{~h}$ before harvest. Each datum point represents the mean \pm range of duplicate plates from one representative experiment.

protein synthesis was not significantly affected. ${ }^{3} \mathrm{H}$-Leucine incorporation was similar in carboxylic acid-treated and control cultures $(7,855 \pm 343$ vs. $8,339 \pm 209 \mathrm{dpm} / \mu \mathrm{g}$ protein, mean \pm SEM, $n=3$, NS).

Cultures were treated and then pulse labeled for $10 \mathrm{~h}$, followed by chase incubation for up to $49 \mathrm{~h}$. The results suggest that there was no effect on $\left[{ }^{3} \mathrm{H}\right] \mathrm{GAG}$ degradation over the duration of the chase incubation as would have been reflected by a change in the ratio of precursor incorporation in $n$-butyratetreated cultures to that in controls $(0.29$ at $17 \mathrm{~h}$ and 0.29 at 49 h). Further, there was no evidence of macromolecular degradation, which is consistent with the previously recognized absence of hyaluronidase in these cells (15).

\section{Discussion}

Naturally occurring carboxylic acids such as $n$-butyrate are generated as a natural consequence of cellular metabolism, and yet their physiological role remains incompletely understood. Sodium butyrate has been added to the medium of a variety of cultured cells and numerous effects have been reported. Enzymes such as tyrosine hydroxylase $(16,17)$, choline acetyltransferase (18), acetylcholinesterase (19), catechol-o-methyltransferase (20), glycosyltransferase (21), and adenylate cyclase (22) can be stimulated by the compound. A wide variety of organic acids including carboxylic acids have been shown capable of influencing intracellular $\mathrm{pH}$ (23). Butyrate has also been reported to inhibit cell division (24-26) and to alter cellular morphology (27).

This report demonstrates that $n$-butyrate can exert a significant regulatory effect on the rate of $\left[{ }^{3} \mathrm{H}\right] \mathrm{HA}$ synthesis in human skin fibroblasts. At $1 \mathrm{mM}$, a $27 \%$ stimulation occurred. The compound markedly inhibited the incorporation of either $\left[{ }^{3} \mathrm{H}\right]$ glucosamine or $\left[{ }^{3} \mathrm{H}\right]$ acetate into $\left[{ }^{3} \mathrm{H}\right] \mathrm{HA}$ without altering macromolecular degradation rates at concentrations ranging from 2 to $10 \mathrm{mM}$. The accumulation of $\left[{ }^{35} \mathrm{~S}\right]$ chondroitin sulfate and dermatan sulfate were unaffected, providing further evidence for distinct and perhaps unrelated regulation of sulfated and nonsulfated GAG species.

The mechanism involved in $n$-butyrate inhibition of $\left[{ }^{3} \mathrm{H}\right] \mathrm{HA}$ synthesis is not known, and a number of possibilities exist. The carboxylic acid could have interfered with the cellular uptake of labeled precursor, had nonspecific toxic effects on skin fibroblasts, could have directly affected the acetylation of HA, or could have influenced precursor pool sizes. These possibilities seem unlikely for the following reasons: (a) maximal inhibitory effects were rapidly reversible with the return of synthetic rates to those indistinguishable from untreated cultures; $(b)$ similar results were obtained when cultures were labeled with either $\left[{ }^{3} \mathrm{H}\right]$ acetate or $\left[{ }^{3} \mathrm{H}\right]$ glucosamine, so that changes in very different precursor pools would need to be singularly affected; $(c)$ total cellular protein synthesis as assessed by $\left[{ }^{3} \mathrm{H}\right]$ leucine incorporation into acid insoluble material was unaffected; and $(d) \mathrm{H}_{2}\left[{ }^{35} \mathrm{~S}^{\mathrm{O}} \mathrm{O}_{4}\right.$ incorporation into chondroitin sulfate and dermatan sulfate was also unaffected. The sulfation of these molecules occurs subsequent to acetylation (28), and thus this crucial result demonstrates that $n$-butyrate is not inhibiting GAG acetylation directly, and that the effects on $\left[{ }^{3} \mathrm{H}\right] \mathrm{HA}$ synthesis are quite specific. All experiments were conducted on nonproliferating, confluent cultures, which is important in view of earlier reports that $n$-butyrate can arrest cell division in $G_{1}(24)$. Treatment failed to influence the cell density or protein content of experimental plates.

Another possibility which deserves consideration is that $n$ butyrate is acting by altering the synthetic rate of a protein(s) that is directly involved in the synthesis of $\left[{ }^{3} \mathrm{H}\right] \mathrm{HA}$. A number of recent reports have suggested that carboxylic acids can modify gene expression through effects on DNA methylation (29), chromatin protein phosphorylation (30), ADP ribosylation (31), or acetylation (32). Effects on the degree of acetylation of histone and nonhistone proteins are apparently mediated through an inhibition of deacetylases (33). The relative potencies of $n$-butyrate and propionate in regard to their actions on histone modification (14) are similar to those reported here. Inhibition of $\left[{ }^{3} \mathrm{H}\right] \mathrm{HA}$ synthesis in fibroblasts is rapid, with maximal effects seen within $8 \mathrm{~h}$ of treatment, which perhaps reflects a rapid turnover of the protein species involved in the mediation of the effect.

Short-chain carboxylic acids are capable of influencing the cellular response to specific hormones. Butyrate significantly reduced the number of glucocorticoid binding sites in HeLa $S_{3}$ cells while synergistically enhancing the dexamethasone stimulation of alkaline phosphatase activity (24). The compound decreased the number of $1,25(\mathrm{OH})_{2} \mathrm{D}_{3}$ receptors and reduced 25 hydroxyvitamin $D_{3}-24$ hydroxylase activity in cultured pig kidney cells (34). The abundance of triiodothyronine receptors, the rate of prolactin production and triiodothyronine-induced growth hormone synthesis are all modulated by $n$-butyrate in $\mathrm{GH}_{1}$ pituitary adenoma cultures (35). Further studies have disclosed that the dose response to the compound was biphasic, with small increases in receptor number after exposure to $0.5-$ $1 \mathrm{mM}$ butyrate and a marked decrease at concentrations up to $10 \mathrm{mM}$ (36). Thus the dose relationship of $n$-butyrate in that culture model is quite similar to its effect on fibroblast HA synthesis reported here.

Early studies demonstrated that very high concentrations of carboxylic acids are generated in the mammalian large intestine by fermentation of dietary carbohydrates (37). An important source appears to be plant cell wall carbohydrates (37). Because short-chain fatty acids comprise the major solute fraction of stool water in humans (38), the colonic tissue is exposed to a total carboxylic acid concentration of nearly $200 \mathrm{mM}$ (13); thus, the inhibition of HA synthesis observed in cultured colon fibroblasts may reflect a physiologically relevant control mechanism 
operant in the intestine in vivo and perhaps in other mammalian tissues.

Studies performed in vitro offer important advantages over those conducted in whole animals. They offer the opportunity to assess the biological role of regulators of metabolism in isolated, homogeneous cell populations under stringently controlled experimental conditions. Because the behavior of cells maintained in culture may differ from that in situ in fundamental ways, observations made in these models should complement rather than replace those conducted in whole animals. Thus, the results reported here ultimately need to be extended by further studies in isolated tissue preparations and in the intact organism.

Information currently available concerning the control of HA synthesis is limited. The results of the current study define a novel probe for regulating specifically $H A$ synthesis at an as yet undefined site. The concentrations used to achieve these effects were identical to those in other experimental systems and are similar to those generated in vivo. The precise mechanistic nature of this carboxylic acid effect and its relationship to the hormonal regulation of HA synthesis are under investigation.

\section{Acknowledgments}

The author wishes to thank Ms. B. K. Howerton for her expert technical assistance and to thank Ms. Pauline A. Thompson and Ruth Harvey for their help in preparing the manuscript.

This work was funded in part by the Medical Research Service of the Veterans Administration. Dr. Smith was a Research Associate in the Veterans Administration Career Development Program.

\section{References}

1. Kraemer, P. M. 1972. Complex carbohydrates of mammalian cells in culture. In Growth, Nutrition and Metabolism in Cells in Culture. Vol. 1. G. Rothblat and V. Cristofalo, editors. Academic Press, Inc., New York. 372-425.

2. Hopwood, J. J., and A. Dorfman. 1977. Glycosaminoglycan synthesis in cultured human skin fibroblasts after transformation with simian virus 40. J. Biol. Chem. 252:4777-4785.

3. Philipson, L. H., and N. B. Schwartz. 1984. Subcellular localization of hyaluronate synthetase in oligodendroglioma cells. J. Biol. Chem. 259:5017-5023.

4. Turakainen, H., H. Larjava, H. Saarni, and R. Penttinen. 1980. Synthesis of hyaluronic acid and collagen in skin fibroblasts cultured from patients with osteogenesis imperfecta. Biochim. Biophys. Acta 628: 388-397.

5. Lamberg, S. I., and A. Dorfman. 1973. Synthesis and degradation of hyaluronic acid in the cultured fibroblast of Marfan's disease. J. Clin. Invest. 52:2428-2433.

6. Smith, T. J., Y. Murata, A. L. Horwitz, L. Philipson, and S. Refetoff. 1982. Regulation of glycosaminoglycan synthesis by thyroid hormone in vitro. J. Clin. Invest. 70:1066-1073.

7. Smith, T. J. 1984. Dexamethasone regulation of glycosaminoglycan synthesis in cultured human skin fibroblasts. Similar effects of glucocorticoid and thyroid hormones. J. Clin. Invest. 74:2157-2163.

8. Riggs, M. G., R. G. Whittaker, J. R. Neumann, and V. M. Ingram. 1977. n-Butyrate causes histone modification in HeLa and Friend erythroleukaemia cells. Nature (Lond.). 268:462-464.

9. Boffa, L. C., G. Vidali, R. S. Mann, and V. G. Allfrey. 1978.
Suppression of histone deacetylation in vivo and in vitro by sodium butyrate. J. Biol. Chem. 253:3364-3366.

10. Smith, T. J., A. L. Horwitz, and S. Refetoff. 1981. The effect of thyroid hormone on glycosaminoglycan accumulation in human skin fibroblasts. Endocrinology 108:2397-2399.

11. Lowry, O. H., N. J. Rosebrough, A. L. Farr, and R. J. Randall. 1951. Protein measurement with the Folin phenol reagent. J. Biol. Chem. 193:265-275.

12. Dische, F. 1947. A specific color reaction for glucuronic acid. $J$. Biol. Chem. 171:725-730.

13. McNeil, N. I., J. H. Cummings, and W. P. T. James. 1978. Short chain fatty acid absorption by the human large intestine. Gut. 19:819822.

14. Sealy, L., and R. Chalkley. 1978. The effect of sodium butyrate on histone modification. Cell 14:115-121.

15. Arbogast, B., J. J. Hopwood, and A. Dorfman. 1975. Absence of hyaluronidase in cultured human skin fibroblasts. Biochem. Biophys. Res. Commun. 67:376-382.

16. Waymire, J. C., N. Weiner, and K. N. Prasad. 1972. Regulation of tyrosine hydroxylase activity in cultured mouse neuroblastoma cells: elevation induced by analogues of adenosine 3',5'-cyclic monophosphate. Proc. Natl. Acad. Sci. USA. 69:2241-2245.

17. Richelson, E. 1973. Stimulation of tyrosine hydroxylase activity in an adrenergic clone of mouse neuroblastoma by dibutyryl cyclic AMP. Nature New Biology 242:175-177.

18. Prasad, K. N., and B. Mandal. 1973. Choline acetyltransferase level in cyclic AMP and $\mathrm{x}$-ray induced morphologically differentiated neuroblastoma cells in culture. Cytobiologie. 8:75-80.

19. Prasad, K. N., and A. Vernadakis. 1972. Morphological and biochemical study in $\mathrm{x}$-ray and dibutyryl cyclic AMP-induced differentiated neuroblastoma cells. Exp. Cell Res. 70:27-32.

20. Prasad, K. N., and B. Mandal. 1972. Catechol-o-methyltransferase activity in dibutyryl cyclic AMP, prostaglandin and X-ray induced differentiated neuroblastoma cell culture. Exp. Cell Res. 74:532-534.

21. Fishman, P. H., J. L. Simmons, R. O. Brody, and E. Freese. 1974. Induction of glycolipid biosynthesis by sodium butyrate in HeLa cells. Biochem. Biophys. Res. Commun. 59:292-299.

22. Prasad, K. N., K. N. Gilmer, and S. Kumar. 1973. Morphologically "differentiated" mouse neuroblastoma cells induced by noncyclic AMP agent: levels of cyclic AMP, nucleic acid and protein. Proc. Soc. Exp. Biol. Med. 143:1168-1171.

23. de Hemptinne, A., R. Marrannes, and B. Vanheel. 1983. Influence of organic acids on intracellular pH. Am. J. Physiol. 245:C178-C183.

24. Littlefield, B. A., N. B. Cidlowski, and J. A. Cidlowski. 1980. Modulation of glucocorticoid effects and steroid receptor binding in butyrate-treated HeLa $\mathrm{S}_{3}$ cells. Arch. Biochem. Biophys. 201:174-184.

25. Ginsburg, E., D. Salomon, T. Sreevalson, and E. Freese. 1973. Growth inhibition and morphological changes caused by lipophilic acids in mammalian cells. Proc. Natl. Acad. Sci. USA. 70:2457-2461.

26. Helson, L., K. Lai, and C. W. Young. 1974. Papaverine-induced changes in cultured human melanoma cells. Biochem. Pharmacol. 23: 2917-2920.

27. Johnson, G. S., R. M. Friedman, and I. Pastan. 1971. Restoration of several morphological characteristics of normal fibroblasts in sarcoma cells treated with adenosine $3^{\prime}, 5^{\prime}$ cyclic monophosphate and its derivatives. Proc. Natl. Acad. Sci. USA. 68:425-429.

28. Roden, L., and M. Horwitz. 1978. Proteoglycans and structural glycoproteins. In The Glycoproteins. Vol. 1. M. Horwitz and W. Pigman, editors. Academic Press, Inc., New York. 3-72.

29. Christman, J. K., N. Weich, B. Schoenbrun, N. Schneiderman, and G. Acs. 1980. Hypomethylation of DNA during differentiation of Friend erythroleukemia cells. J. Cell Biol. 86:366-370. 
30. Boffa, L. C., R. J. Gruss, and V. G. Allfrey. 1981. Manifold effects of sodium butyrate on nuclear function. J. Biol. Chem. 256:96129621.

31. Rastl, E., and P. Swetly. 1978. Expression of poly (adenosine diphosphate-ribose) polymerase activity in erythroleukemic mouse cells during cell cycle and erythropoietic differentiation. J. Biol. Chem. 253: $4333-4340$.

32. Kruh, J. 1982. Effects of sodium butyrate, a new pharmacological agent, on cells in culture. Mol. Cell Biochem. 42:65-82.

33. Cousens, L. S., D. Gallwitz, and B. M. Alberts. 1979. Different accessibilities in chromatin to histone acetylase. J. Biol. Chem. 254:17161723.

34. Costa, E. M., and D. Feldman. 1985. Modulation of $1,25(\mathrm{OH})_{2} \mathrm{D}_{3}$ receptor binding and action by sodium butyrate in cultured pig kidney cells (LLC-PK ${ }_{1}$ ). Prog. Endocrinol. Soc. Annu. Meet. (Baltimore), 67th. p. 261.

35. Samuels, H. H., F. Stanley, J. Casanova, and T. C. Shao. 1980. Thyroid hormone nuclear receptor levels are influenced by the acetylation of chromatin-associated proteins. J. Biol. Chem. 255:2499-2508.

36. Stanley, F., and H. H. Samuels. 1984. n-Butyrate effects thyroid hormone stimulation of prolactin production and mRNA levels in $\mathbf{G H}_{1}$ cells. J. Biol. Chem. 259:9768-9775.

37. Cummings, J. H. 1981. Short chain fatty acids in the human colon. Gut. 22:763-779.

38. Ruppin, H., S. Bar-Meir, K. H. Soergel, C. M. Wood, and M. G. Schmitt, Jr. 1980. Absorption of short-chain fatty acids by the colon. Gastroenterology. 78:1500-1507. 